NOTE:

\title{
TITLE VII, MULTIPLE LINEAR REGRESSION MODELS, AND THE COURTS: AN ANALYSIS
}

I

\section{INTRODUCTION}

Since its introduction in the 1970 's, ${ }^{1}$ multiple linear regression analysis has become an increasingly used and effective means of proof in litigation arising under Title VII of the Civil Rights Act of $1964 .^{2}$ Its success is due to its capacity to provide a more focused analysis of an employer's work force than the less sophisticated techniques that had previously been used. ${ }^{3}$ Regression analysis can filter out the effects of several legitimate factors on an employment decision, such as education and experience, and focus on whether discrimination is also a factor. This capacity has proved quite valuable to the courts. Indeed, two federal circuit courts of appeals have held against plaintiffs because they did not present statistics that adequately controlled for several variables. ${ }^{4}$ Consequently, even greater use of regression analysis along with other multivariate statistical methods can be expected in the future.

Regression analysis, however, has challenged the attorneys and courts who must present and evaluate it. It presents issues that can be extremely difficult to resolve. One need only peruse the court's 165-page opinion in Vupanich v. Republic National Bank of Dallas ${ }^{5}$ to appreciate the potentially overwhelming burden that can be thrust on a court in an all-out statistical battle. Fortunately, many of the

\footnotetext{
Copyright (C) 1983 by Law and Contemporary Problems

1. Multivariate statistical models were apparently first suggested for use in employment discrimination cases in Note, Beyond the Prima Facie Case in Employment Discrimination Law: Statistical Proof and Rebuttal, 89 HARV. L. REV. 387 (1975).

2. 42 U.S.C. $\S 2000$ e (1976 \& Supp. III 1979), amended by General Accounting Office Personnel Act of $1980, \S 8(\mathrm{~g}), 42$ U.S.C.A. $\S 2000 \mathrm{e}-16$ (West Supp. 1980) (originally enacted as Civil Rights Act of 1964 , $\S \S 1971,1975$ a to $1975 d$, 2000a-2000h-6, Pub. L. No. 88-352, Title VII, § 70l, 78 Stat. 253 (1964)) (hereinafter cited as Title VIII.

3. E.g., Coble v. Hot Springs School Dist. No. 6, 682 F.2d 721, 730 (8th Cir. 1982) (average salary statistics held insufficient to establish a prima facie case). For a complete discussion of the kinds of statistical analysis used in employment discrimination litigation, see D. BaLdus \& J. COLE, STATISTICAL ProOr of Discrimination (1980); W. Connolly \& D. Peterson, Use of Statistics in Equal Emploiment OPPORTUNITY LITIGATION (1982).

4. Coble v. Hot Springs School Dist. No. 6, 682 F.2d 721, 730 (8th Cir. 1982) (suggests multiple regression analysis should have been used); Pouncy v. Prudential Ins. Co. of Am., 668 F.2d 795, 802-03 (5th Cir. 1982); Wilkins v. University of Houston, 654 F.2d 388, 402 (5th Cir. 1981); see also Valentino v. United States Postal Serv., 674 F.2d 56, 66-67 (D.C. Cir. 1982) (plaintiffs required to control for "minimum objective qualifications" to establish a prima facie case).
}

5. 505 F. Supp. $22+$ (N.D. Tex. 1980). 
problems caused by regression analysis can be alleviated as the legal profession becomes more familiar with the capabilities and limitations of those models and as case law develops to provide guidelines for their use. This note examines the judicial reception of multiple linear regression analysis, focuses on how the courts have dealt with the particular strengths and weaknesses of the model, and suggests modifications to the case law that would help achieve two objectives-maximization of the truth-finding capacity of multivariate models, and simplification of the judicial task.

\section{Multiple Linear Regression Analysis}

Multiple linear regression analysis is a process for estimating the relationships among several variables. For example, it can be used to estimate the extent to which employee pay at a certain factory depends jointly on seniority, level of education, and gender. In such an application, employee pay is termed the dependent variable; and seniority, level of education, and gender are called independent or explanatory variables. If the regression indicates that employee pay depends at least in part on employee gender, it may be because the employer in fact discriminates by gender in the assignment of pay, or it may be due to technical imperfections in the regression analysis. ${ }^{6}$ Whether the correlation between gender and rate of pay was caused by discrimination or some legitimate factor can only be determined by evaluating the validity of the regression in light of the facts and circumstances of the particular case. ${ }^{7}$

This note examines two major threats to the validity of a multiple regression analysis:

(1) functional form issues - the extent to which the mathematical assumptions of a model are actually reflected in the defendant's decision procedures; and

(2) completeness issues-the type and number of variables included in the model, and the accuracy of their quantification.

\section{III}

\section{Functional Form Issues}

The functional form of a regression model is the mathematical formula chosen to describe the particular employment practice in issue. Inherent in this formula are mathematical assumptions about how the independent variables affect the dependent variable. These assumptions are the source of both the strengths and

6. For a fuller explanation of multiple regression analysis in the context of employment discrimination litigation, see D. Baldus \& J. Cole, supra note $3, \S \S 6.0-6.3,8.0-8$ A.4; W. Connolly \& D. Peterson, supra note 3, $\$ \S 9.03(2), 11.03$, app. B; Barnett, An Underestimated Threat lo Multiple Regression Analysis Used in Job Discrimination Cases, 5 Indus. REL. L.J. 156 (1982); Fisher, Multiple Regression in Legal Proceedings, 80 Colum. L. REv. 702 (1980); Peterson, Pitfalls in the Use of Regression Analysis for the Measurement of Equal Employment Opportunity, 5 InT'L J. POL'y Analysis \& Information Sys. 43 (1981); Risher \& Cameron, Pay Decisions: Testing for Discrimination, 7 EMPlovee ReL. L.J. 432 (1981); Note, supra note 1.

7. See D. Baldus \& J. Cole, supra note 3, $\S \S 8.021(1), 9.02,9.42$; Smith \& Abram, Quantitative Analysis and Proof of Employment Discrimination, 1981 U. ILL. L. REV. 33, 48. 
weaknesses of multiple regression analysis. Because they impose a structure on the qualifications of the defendant's employees, no matter how diverse, several independent variables can be handled without a large sample size. Comparisons can be made between all employees, even though some may have particular combinations of qualifications unmatched by any other employee. ${ }^{8}$ If the formula includes faulty assumptions, however, the regression can give a false indication of disparity in treatment, and the bias can be very difficult to detect. ${ }^{9}$

Despite this inherent weakness, functional form arguments rarely appear in the case law on multiple regression analysis, perhaps because they are not easily understood without statistical training. One case in which a functional form issue was raised is Pennsylvania v. Local 542, International Union of Operating Engineers. ${ }^{10}$ The plaintiff had presented several regressions in which the dependent variable was hours of work per year, and the independent variables were age, district, branch, seniority, and out-of-work status. The regressions were in linear form-every one unit increase in an independent variable was assumed to have the same effect on the dependent variable. " Thus, hours of work were assumed to increase the same amount for a worker's first year of seniority as for his tenth or twentieth year. The regressions indicated that minority workers received 109 fewer hours of work per year than nonminority workers. ${ }^{12}$ One of the defendants' objections to the regressions was that the linear form was inappropriate, and the plaintiffs' expert erred when he testified that tests of statistical significance tended to show that the linear form was appropriate. The defendants were unable, however, to produce any statistical analysis that legitimately explained the disparity in hours of work per year. ${ }^{13}$ While it understood that tests of satistical significance could not prove the appropriateness of the linear form, the court still rejected the defendants' argument as not a very "serious" one. One of the reasons for its conclusion was that the plaintiffs' expert had also testified that he had performed a nonlinear regression and achieved results comparable to those of the linear regressions. ${ }^{14}$

A defendant had more success with a functional form argument in Presseisen $v$. Swarthmore College. ${ }^{15}$ The plaintiffs had alleged salary discrimination against female faculty members at Swarthmore, and they presented regressions indicating a correlation of salary with gender after controlling for age, years since highest degree, years at Swarthmore, type of educational degree, and division of the

8. See D. BaLdus \& J. Cole, supra note $3, \S 8.022(1)$.

9. A computer will accept whatever formula is chosen and perform the necessary calculations no matter how inappropriate the formula. Also, the usual tests of statistical significance cannot be relied upon to determine the appropriateness of the regression formula. See id. $\$ \$ 8.022(2), 8.21 ;$ W. ConNOLLY \& D. Peter son, supra note 3, $\$ 11.03$; Barnett, supra note 6 , at 160; Fisher, supra note 6 , at 708 ; Peterson, supra note 6 , at 64; Risher \& Cameron, supra note 6 , at 433 .

10. 469 F. Supp. 329 (E.D. Pa. 1978).

11. See D. Baldus \& J. Cole, supra note $3, \S 8$ A.21; W. Connolly \& D. Peterson, supra note 3 , $\S 1103$ \& app. A; Barnett, supra note 6, at 163-65; Fisher, supra note 6 , at $711-12$ n.20; Peterson, supra note 6 , at 53-56; Risher \& Cameron, supra note 6 , at 441 .

12. 469 F. Supp. at 354 .

13. See infra note 22 .

14. 469 F. Supp. at 377-79; see also Trout v. Hidalgo, 517 F. Supp. 873, 879 n.14 (D.1.C. 1981) (plaintiffs presented nonlinear regression that produced results consistent with their linear regressions).

15. 442 F. Supp. 593 (E.D. Pa. 1977). 
college in which the person was employed. Swarthmore alleged that the regressions were biased because salaries in male-dominated divisions of the college increased at higher rates than those in divisions that were mixed with males and females. One proposed legitimate explanation for the difference in rates was economic factors; physics professors, for example, were in shorter supply than English professors and could therefore command greater increases in salary. ${ }^{16}$ Swarthmore was apparently arguing that the additivity assumption of an ordinary least squares regression was not satisfied. The additivity assumption states that the effects of independent variables on the dependent variable are completely unrelated. ${ }^{17}$ Swarthmore alleged that the effects of division on salary interacted with those of other variables, such as years at Swarthmore, and thereby biased the regressions. To support this allegation, Swarthmore presented a regression that corrected the error and indicated salary was not correlated with gender. The court accepted this argument as a valid criticism of the plaintiffs' regressions. ${ }^{18}$

Local 542 and Presseissen demonstrate a satisfactory approach for the resolution of functional form issues. Functional form errors can seriously bias a regression model, but nearly all regressions are at least theoretically vulnerable to an argument that their mathematical assumptions are not satisfied. Because the assumptions will rarely appear to be completely satisfied, the usefulness of regression analysis could be quite limited if such arguments were accepted without supporting evidence. Requiring the party making a functional form argument to present a model that controls for the alleged error and reaches a different result is not an onerous burden, and it will certainly eliminate many spurious arguments that could be used to attack regression analysis. Once such an opposing model is presented, the courts will find it much easier to resolve the functional form issue in the context of determining which of two models is more valid than in evaluating one regression according to some abstract standard of validity. ${ }^{19}$

IV

\section{COMPLETENESS ISSUES}

Another aspect of a regression model that must be evaluated before any inferences can be drawn from its results is the completeness of the model-the type and number of variables included, and the accuracy of their quantification. Obviously, this endeavor can be very imprecise. The number of factors that could conceivably affect an employment decision is practically unlimited. Also, many factors are simply not amenable to quantification. Job preferences, individual

16. Id. at 615-16.

17. See D. Baldus \& J. Cole, supra note $3, \$ 8 \mathrm{~A} .22$.

18. $442 \mathrm{~F}$. Supp. at 617,619 . While it was not clearly described by the court, Swarthmore's rebutting regression did include a variable for the level of a professor's initial placement-either junior or senior appointment. The inclusion of this variable could well have biased the rebutting regression in favor of Swarthmore if Swarthmore had discriminated in initial placement. For a discussion of tainted variables, see infra text accompanying note 21.

19. See D. Baldus \& J. Cole, supra note $3, \S 8.22$ \& viii (1980 \& Supp. 1982); Finkelstein. Regression Models in Administrative Proceedings, 86 HARV. L. REV. 1442, 1466 (1973); see also Trout v. Hidalgo, 517 F. Supp. 873, 882 (D.D.C. 1981) (citing Finkelstein). 
motivation, and quality of education can significantly affect an employment decision, yet these factors and others like them can be extremely difficult to capture in a mathematical formula. Thus, as with functional form arguments, almost any regression is vulnerable to a hypothetical argument that its results are biased because a particular variable was omitted or inaccurately quantified.

This vulnerability does not, however, destroy the usefulness of multiple regression analysis in Title VII litigation. Three conditions should be satisfied before a completeness argument discredits a regression model. These conditions are best explained in an example. Suppose that a plaintiff has produced a regression that indicates a statistically significant correlation of salary with gender, and the defendant alleges the model is biased because it did not include the variable "supervisory ability." One condition that should be satisfied before the defendant's argument is accepted is that the omission must have caused the regression systematically to overvalue the qualifications of female employees-females must actually have less supervisory ability than males. This condition can eliminate many spurious omitted variable arguments. While the courts may not be willing to presume that qualifications such as amount of education and experience are equally distributed among persons of different races and sexes, they are likely to presume that qualifications such as supervisory ability and personal motivation are equally distributed, especially in the absence of reliable evidence to the contrary. ${ }^{20}$

Another condition for acceptance of a completeness argument is that the variable in question must not be tainted, for example, one that conceals the effects of the defendant's discrimination. ${ }^{21}$ For instance, in the example, assuming the

20. See Valentino v. United States Postal Serv., 674 F.2d 56, 71 n.24 (D.C. Cir. 1982) (court refused to assume "equal qualifications" for threshold or minimim objective qualifications, but would not have required the plaintiff to control for subjective qualifications or attributes of relative advantage at the prima facie stage); Trout v. Hidalgo, 517 F. Supp. 873, 881 (D.D.C. 1981) (court refused to accept "mere sex stereotypes" as adequate rebuttal of plaintiffs regressions; plaintiff had not controlled for the variables type and quality of experience and education, and had used age as a proxy for years of experience); Segar v. Civiletti, 508 F. Supp. 690, 696 n.2 (D.D.C. 1981) (plaintiff need only control for variables that are objective in nature and quantifiable); Vuyanich v. Republic Nat'l Bank, 505 F. Supp. 224, 306-07, 310 (N.D. Tex. 1980) (court refused to accept on the basis of a "few social science articles" the defendant's argument that blacks and females possessed fewer "miscellaneous productivity influences" such as career motivation, creativity, and supervisory capability). Conira Agarwal v. Arthur G. McKee \& Co., 19 Fair Empl. Prac. Cas. (BNA) 503, 506 (N.D. Cal. 1977), affd, Fair Empl. Prac. Cas. (BNA) 1565 (9th Cir. 1981) (plaintiffs regressions were considered defective because they failed to control for quality of education and experience and "special abilities or characteristics" which might have had some bearing upon salary).

21. In most of the cases dealing with tainted variable arguments, the variable in question was some form of job level. See infra notes 24-46 and accompanying text for an analysis of the use of job level in regression models. For cases in which the allegedly tainted variable was not job level, see James v. Stockham Valves \& Fittings Co., 559 F.2d 310, 332 (5th Cir. 1977), cert. denied, 434 U.S. 1034 (1978) (merit rating was not an appropriate variable because it was determined by overwhelmingly white supervisors; years of education was not an appropriate variable because it was irrelevant to adequate job performance); Coates v. Johnson \& Johnson, 28 Empl. Prac. Dec. (CCH) I 32,664, at 25,028-29 (N.D. Ill. 1982) (disciplinary actions was an appropriate variable because no evidence was presented showing the defendant had discriminatorily taken disciplinary actions; black supervisors and managers equaled or exceeded the representation of blacks in the work force); Mecklenburg v. Montana State Bd. of Regents, 13 Fair Empl. Prac. Cas. (BNA) 462, 468 (D. Mont. 1976) (nursing was inappropriate variable because nurses were overwhelmingly female, and it was "impossible to conclude that any disparity in salaries due to the 'nursing' variable was attributable to the fact that the individuals involved were nurses or that they were female"). 
defendant does produce evidence indicating that females have less supervisory ability than males, the source of the evidence must be questioned. If supervisory ability was determined by the defendant, and it discriminated in making the determination, including supervisory ability in the regression would conceal this discrimination and bias the regression in favor of the defendant.

The third condition that should be satisfied before a completeness argument discredits a regression is that correction of the alleged error or errors must cause the regression to reach a different result-the presence or absence of a statistically significant correlation of treatment with group status. In the example, including supervisory ability in the regression should completely explain the disparity in salary between males and females, or at least reduce it to a statistically insignificant level. This condition can also greatly help a court in deciding cases, since difficult issues that have only a minor impact on the regression can be avoided. ${ }^{22}$

Perhaps because they are more intuitive than functional form issues, these completeness issues have dominated the case law on multiple regression analysis. While the particular variables required in an accurate model will naturally depend on the facts of individual cases, two completeness issues have arisen quite frequently in Title VII litigation, and the courts have reached widely varying conclusions on these issues. They are:

(1) the role of job classification and job level variables in a regression model; and

(2) the allocation of the burden of producing reliable data about a defendant's work force.

\section{A. Job Classification and Job Level}

Of all the complex issues that can arise when evaluating a regression model, the courts have been most confused in their treatment of job classification and job level variables. Job classification involves the type of employee, such as engineer, computer programmer, or secretary. Job level is the rank of an employee within the defendant's work force hierarchy. Obviously, job classification and job level are related since an employee's job classification is a significant determinant of the job level he can achieve. Their effects when included in a regression, however, are quite different. Job classification is largely determined by forces external to an employer, and factors such as economic forces and productivity can legitimately cause differing treatment between job classifications. ${ }^{23}$ An engineer will usually receive more pay than a secretary. Also, job classification can help control for other variables such as type of education and experience. ${ }^{24}$ Job level, on the other

22. A case demonstrating the value of this condition to a court is Pennsylvania v. Local 542, Int'l Union of Operating Eng'rs, 469 F. Supp. 329, 378-79 (E.D. Pa. 1978). The defendant attacked the plainiff's regressions because they omitted variables such as skills, willingness to travel, refusal of jobs, and initial method of entry into employment. The defendant's own regressions, however, included these factors and only reduced the disparity in hours worked per year between blacks and whites from 109 to 79 . The court quite properly held that the plaintiffs regressions were not discredited.

23. Of course, job classification can also be a tainted variable if it is within the control of the defendant. See James v. Stockham Valves \& Fittings Co., 559 F.2d 310, 332 (5th Cir. 1977) (skill level was inappropriate variable because the defendant had systematically excluded blacks from training opportunities to obtain skills).

24. See Trout v. Hidalgo, 517 F. Supp. $873,883 \&$ n.34 (D.D.C. 1981 ). 
hand, is more a result than a determinant of the defendant's employment practices, and could therefore easily be a tainted variable. Specifically, the defendant's initial placement and promotion practices are important determinants of an employee's job level. If this variable is included in a regression, the effects of any discrimination in these practices will be attributed to job level and not group status. The regression would instead focus on the issue of whether employees received equal pay within job levels, which may be desirable if that is the disputed issue. $^{25}$

Some courts have recognized the distinction between job classification and job level, and, while concluding that job classification is a necessary variable, have rejected the inclusion of job level. ${ }^{26}$ The leading case is Valentino $v$. United States Postal Service. ${ }^{27}$ The plaintiff in Valentino represented all females who were employed in the upper echelons of the Postal Service Headquarters in Washington, D.C., and who had been denied advancement on the basis of their sex. These upper echelons included the job classifications of "economist, engineer, lawyer, computer expert, statistician, accountant, business manager, [and] secretary."28 The plaintiff introduced regression analyses in which the dependent variable was salary, and the independent variables were sex, length of government service, and years of education. While the court noted "[h]er analyses might have been impressive [if] . . . women and men in the employer's work force held similar jobs," the failure to control for the widely varying job classifications "stripped her analyses of the significance she would attribute to them." 29 To support this conclusion, the court cited statistics showing that men received a large proportion of degrees in fields such as law, engineering, and the sciences, while women received a large proportion of degrees in fields such as education, the humanities, and nursing. The court also noted the plaintiff had access to the occupational codes of the defendant's employees but did not utilize them. ${ }^{30}$

This holding seems correct, although one would have hoped for more evidence keyed to the defendant's work force indicating women were in fact clustered in lesser paying job classifications. If this were the case, the plaintiff's regressions were biased because they systematically overvalued the qualifications of women in the lesser paying classifications by equating them with those of men in the higher paying ones. Valentino should not be interpreted, however, as requiring plaintiffs to make refined distinctions among the differing job classifications in a defendant's work force. The court itself said: "The burden of comparing appropriate groups in

25. See Vuyanich v. Republic Nat'l Bank, 505 F. Supp. 224, 320-21 (N.D. Tex. 1980) (plaintif's arguments concerning the effect of including job level in a regression model).

26. Valentino v. United States Postal Serv., 674 F.2d 56 (D.C. Cir. 1982); James v. Stockham Valves \& Fittings Co., 559 F.2d 320, 332 (5th Cir. 1977) (skill level inappropriate variable because it was a function of job level); Key v. Gillette Co., 29 Empl. Prac. Dec. (CCH) | 32,909, at 26,309 (D.D.C. 1982) (type of education not properly controlled for because of widely varying job classifications); Trout v. Hidalgo, 517 F. Supp. 873, 883 n.34, 886 n.47 (D.D.C. 1981); Greenspan v. Automobile Club, 495 F. Supp. 1021 , 1063-65 (E.D. Mich. 1980) (job level held inappropriate variable); Mecklenburg v. Montana State Bd. of Regents, 13 Fair Empl. Prac. Cas. (BNA) 462, 468 (D. Mont. 1976) (job level held inappropriate variable).

27. 674 F.2d 56 (D.C. Cir. 1972).

28. Id. at 71 .

29. Id. at $70-71$.

30. Id. at $71 \mathrm{nn} .22 \& 23$. 
terms of minimum objective qualifications, onerous here because of the disparate occupational categories involved, is far more tractable when all members of the class are professional, administrative, or technical employees with generally similar job skills and seek advancement to positions involving those same skills." 31 The court also expressly noted that it did not consider the plaintiff's regressions flawed because they did not include job level. ${ }^{32}$

Other cases have failed to recognize the distinction between job classification and job level. ${ }^{33}$ In Agarwal v. Arthur G. McKee $\mathcal{E}^{2} C o .,{ }^{34}$ the plaintiff represented members of several minority groups who were employed by Western Knapp Engineering (WKE), excluding office, clerical, and service workers. WKE specialized in the creation of production facilities required by the mining, steel, chemical, and petroleum industries. Its divisions included sales and marketing, project operations, project management, and administration. The plaintiff alleged that discrimination had prevented minorities from being initially placed or promoted into the top six of seventeen salary levels at WKE. ${ }^{35}$ In support of this allegation, it presented regression analyses in which the dependent variable was salary, and the independent variables were minority status, total years of education, number of years since receipt of highest degree, age of employee, age of employee squared, type of professional registration held by the employee, years of prior experience, years of prior experience at McKee, years of experience at McKee squared, and number of years of any break in service at McKee. ${ }^{36}$ After controlling for these factors, minorities still received $\$ 251$ less per month than nonminorities. ${ }^{37}$

The court held that the regressions were not probative because they "failed to treat salary as a function of job position and salary grade. Furthermore, plaintiff treated all job positions as fungible, involving equal levels of knowledge, skill, and responsibility. Therefore, plaintiff's statistics do not refute defendant's contention that salary differences between minorities and nonminorities within each job position are not substantial."38 This last sentence refers to WKE's statistics showing that differences in the average salaries of minorities and nonminorities within job positions were not statistically significant. Examples of such job positions were draftsman, senior draftsman, designer, and senior designer. ${ }^{39}$ Thus, the job position variable was a combination of job level and job classification, and it retained all the dangers inherent in the use of a job level variable.

31. Id. at 68. The court cited Trout v. Hidalgo, 517 F. Supp. 873 (D.D.C. 1981), in support of this proposition. The plaintiff class in Trout was composed of all female professional technical employees of the Navy Regional Data Automation Center. Id. at 877 . See infra text accompanying notes $49-56$ for a discussion of Trout.

32. 674 F.2d at 71 n. 26 .

33. EEOC v. Federal Reserve Bank, 30 Fair Empl. Prac. Cas. (BNA) 1137, 1154-55 (4th Cir. 1983) (cases dealing with the distinct issues of job classification, job level, and average salary statistics were cited as dealing with the same issue).

34. 19 Fair Empl. Prac. Cas. (BNA) 503 (N.D. Cal. 1977), affd, 25 Fair Empl. Prac. Cas. (BNA) 1565 (9th Cir. 1981).

35. Id. at 504-05.

36. Id. at 506 .

37. Id. at 512 .

38. Id.

39. Id. at 511 . 
The court may have erred in holding that the WKE's job position statistics discredited the plaintiff's regressions. From what can be gathered from the court's opinion, the plaintiff never alleged that minorities received lesser salaries than nonminorities within job positions. Instead, the plaintiff contended minorities could not attain the higher job positions because of discrimination. WKE's statistics showing no disparity between the average salaries of minorities and nonminorities within each job position were irrelevant to the disputed issue in the case.

On the other hand, the plaintiff's regressions substantially controlled for job classification by including the variable type of professional registration held by the employee. Also, no evidence was presented showing that minorities were clustered in the lower paying job classifications, and the regressions consequently biased. As a result, one is left with a large disparity in salary between minorities and nonminorities that is not explained by job classification, education, or experience. In the absence of any further explanation, one can certainly infer that this was caused by discriminatory initial placement and promotion practices. By focusing on salaries within job positions, the court apparently missed the thrust of the plaintiff's case.

The same result can occur even when a court recognizes the danger of including job level. ${ }^{40}$ In Presseisen v. Swarthmore College, ${ }^{41}$ the plaintiffs represented female faculty members at Swarthmore, and had alleged sex discrimination in tenure, hiring, promotion, initial placement, and pay. The court rejected the plaintiffs' regressions as proof of pay discrimination primarily because the statistics indicated no disparity in pay between men and women when academic rank was included as a variable. While it recognized that academic rank could conceal the effects of promotion discrimination, the court concluded its inclusion was justified because the court had earlier in its opinion held that Swarthmore had not discriminated in promotions. ${ }^{42}$ Although this reasoning might appear to be correct, it is faulty for two reasons.

First, the court did not seem to realize that discrimination in initial placement could also have been concealed by including academic rank in the regression. This

40. See, e.g., Vuyanich v. Republic Nat'l Bank, 505 F. Supp. 224 (N.D. Tex. 1980), Presseissen v. Swarthmore College, 442 F. Supp. 593 (E.D. Pa. 1977).

In Vuyanich, the court first dealt with salary discrimination, defining it as unequal pay for comparable jobs. It therefore rejected several of the plaintiffs' regressions as proof of salary discrimination because they did not adequately control for comparable jobs. 505 F. Supp. at 284-85, 305. It distinguished James v. Stockham Valves \& Fittings Co., 559 F.2d 310 (5th Cir. 1977), on the ground that James was a job assignment case, while Vuyanich involved wage discrimination. 505 F. Supp. at 305 n.95. But when dealing with the same regressions as proof of initial placement and promotion discrimination, the court inexplicably rejected them for the same reason-they did not adequately control for comparable jobs. Id. at 321 . Thus, plaintiffs were saddled with the burden of not only proving that discrimination caused their unequal salaries, but also the particular kind of discrimination-wage of initial placement and promotion.

The Vuyanich court was consistent, however, since it also rejected the defendant's regressions as proof of salary discrimination because they failed to control for comparable jobs. The court did not say how excluding job level from the regressions would bias them in favor of the defendant. See 505 F. Supp. at 308. It would seem that excluding job level from a regression would favor the defendant (cause a regression to conceal unequal treatment) only if the plaintiff class initially had been placed and promoted more favorably than other employees with similar qualifications, but then had been less favorably treated with regard to salaries within job levels. This would seem to be a highly unlikely occurrence.

41. 442 F. Supp. 593 (E.D. Pa. 1977).

42. Id. at 614,619 . 
failure is especially significant since the court, when dealing specifically with the issue of initial placement discrimination, was disturbed by the fact that no woman had ever been placed in a senior rank. The court, however, held that the plaintiffs had not established a prima facie case of initial placement discrimination because they had failed to carry their burden of presenting additional evidence showing the availability of women for senior appointments. ${ }^{43}$ The court should have realized that the salary regressions were further evidence of initial placement discrimination.

Second, the court had not, in fact, affirmatively held that Swarthmore's promotion practices were nondiscriminatory. Instead, the court stated that all the evidence introduced on the issue had been unreliable and inconclusive. ${ }^{44}$ Once again, the court should have recognized that the salary regressions were additional proof of promotion discrimination. Instead, the failure of proof of promotion discrimination was used to bootstrap the inclusion of academic rank to explain disparities in salary.

The lesson of these cases is that one must not lose sight of the particular issues in dispute in the midst of a barrage of statistics, and one should always keep in mind how the inclusion or exclusion of variables can affect a regression's capacity to illuminate those issues. Especially when the dependent variable is salary, which reflects all of the defendant's treatment of an employee since hiring, ${ }^{45}$ one must realize that a correlation with group status could reflect many different types of discrimination, and a variable such as job level can greatly narrow the focus of the regression.

\section{B. Burden of Producing Data}

The courts have displayed varying approaches to the issue of who bears the burden of producing reliable data on the defendant's work force, or the risk of the absence of such data. The approach most adverse to plaintiffs is found in Aganwal v. Arthur G. McKee $\mathcal{F}^{2}$ Co. ${ }^{46}$ In addition to the reasons already discussed, ${ }^{47}$ the plaintiff's regressions were considered defective because the plaintiff failed to demonstrate that gaps in the defendant's records "had no effect on the overall quality of the regression analysis," even though the "total amount of missing information was not large."48 The regressions were also considered defective because the plaintiff did not verify the accuracy of the data that were in the defendant's records. ${ }^{49}$ Thus, the entire burden of production was allocated to the plaintiff, even though the defendant had control of the records. Presumably, the more

43. Id. at $621,624-25$.

44. "The best that can be said about all of the statistical testimony concerning promotions is that, in this case, it is a very difficult area to statistically harness and the various results do not provide a reliable measurement of anything concerning promotions at Swarthmore." Id. at 613.

45. See W. CONNOLly \& D. PETERSON, supra note $3, \S 9.01$ (discussion of type of practices that can cause pay disparities).

46. 19 Fair Empl. Prac. Cas. (BNA) 503 (N.D. Cal. 1977), affd, 25 Fair Empl. Prac. Cas. (BNA) 1565 (9th Cir. 1981).

47. See supra text accompanying notes 32-37.

48. 19 Fair. Empl. Prac. Cas. (BNA) at 506.

49. Id. 
defective the defendant's record-keeping practices, the more they would have favored the defendant.

A similar approach is found in Key $v$. Gillette Co. ${ }^{50}$ The plaintiff class in Key was composed of female managerial, professional, and supervisory employees at three Gillette facilities and had alleged discrimination in initial placement. ${ }^{51}$ The plaintiffs presented a regression analysis that included the variable "age at time of hire" as a proxy for pre-Gillette experience because a substantial number of employment files were not complete. The court rejected the regressions partly because of the age proxy:

I find that such a substitution is unreasonable, circular, and even a bit dishonest, in a case where the plaintiff is suing on the basis of a statute passed by Congress to correct a cultural situation which results more often than not in men being able to achieve far greater experience than women of equal age. Men and women who have had similar past experience may indeed be similarly situated with respect to the prior experience factor, but that does not in any way support [the plaintiffs expert's] assumption that men and women of equal age are equally experienced. Plaintiff produced no evidence which would support a finding that for the purpose of this suit, age at the time of hire is a good and dependable substitute for past experience. ${ }^{52}$

Thus, plaintiffs bore the burden of the defendant's failure adequately to maintain its personnel files.

An opposite result was reached in Trout $v$. Hidalgo. ${ }^{53}$ In Trout, the plaintiffs represented all female professional technical employees of the Navy Regional Automation Center (NARDAC), and alleged a pattern and practice of sex discrimination in hiring, performance evaluation, job assignment, promotion, and award procedures. ${ }^{54}$ Their proof consisted essentially of multiple regression analyses in which the dependent variable was salary, and the independent variables were level of education, years of NARDAC service, years of other government employment service, years of potential nongovernmental experience between date of receipt of last educational degree and date of entry in federal service, and sex. The regressions indicated that over the years 1972-79 women received salaries that ranged from $\$ 2200$ to $\$ 3500$ less per year than men's salaries. ${ }^{55}$ NARDAC contended the regressions were biased because they omitted the variables type and quality of experience and education, and because the variable years of potential experience between completion of education and date of entry in federal service reflected age more than actual experience. No evidence keyed to its own work force was produced to support these arguments. Instead, NARDAC presented census data showing that technical, computer-related education and experience are not equally distributed in the general population between men and women. NARDAC also presented nonexpert testimony that women are more likely than

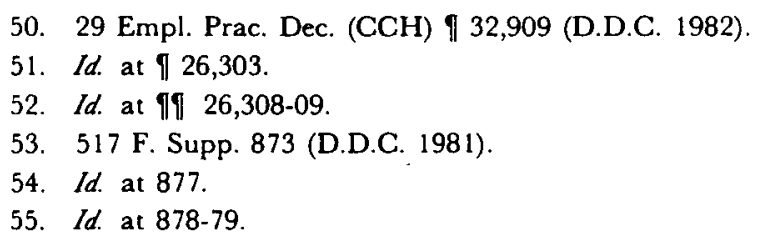


men to leave the labor force to raise children. They argued that women, on the average, have less experience per year of age than men. ${ }^{56}$

The court rejected both of these arguments. The census data and nonexpert testimony were inadequate because the court "would not be justified in accepting mere sex stereotypes as an adequate rebuttal. What was required was substantial, expert supporting evidence keyed to the population here involved, but such evidence was not forthcoming." 57 The court then held that the plaintiff had established a prima facie case:

[P]arties in complicated Title VII actions are increasingly using multiple regression analysis, such as that conducted in the instant case, to separate the phenomenon of discrimination from a myriad of innocent interacting factors. While such analysis can assist significantly in making the refined and sophisticated judgments required, it would be erroneous to impose upon the party relying upon this technique the burden of incorporating every conceivable refinement and disproving every contingency . . . In the case at hand, plaintiffs used regression analysis to attempt to eliminate such possible explanations for the salary differentials as educational and experience factors. They succeeded in doing so to a substantial extent. The government argues, in essence, that because plaintiffs did not refine the variables in their regression to an absolute degree, they failed in meeting the required burden of proof. The Court declines to impose upon Title VII plaintiffs so impractical a requirement. ${ }^{58}$

The court noted that this conclusion was especially compelling because the plaintiffs had requested further information about the NARDAC work force but were only told that much of the information was unavailable. ${ }^{59}$ Also, the defendant had failed to include in its own regressions the variables type and quality of education and experience, and a more accurate prior experience proxy. The court stated that this "must be interpreted as a concession that these refinements in the specification of the model would not have affected the rejection of the hypothesis of no discrimination."60

The result in Trout seems far more justifiable than those in Agarwal and Key. In all three cases the plaintiffs used the best information available in their regressions. The real issue was who would bear the burden of the defendants' failure to maintain adequate records on their own work forces. In Agarwal and Key the defendants were rewarded for their inadequate records. In Trout, they were penalized. The latter approach ensures that the truth-finding capacity of multiple regression analysis will be maximized. Its capacity simultaneously to control for several qualifications is useless if no data are available on how the qualifications are distributed in a defendant's work force. Placing a burden of production on the defendant ensures that the party with the greatest opportunity and resources to supply the necessary data has the incentive to do so.

Also, the court's rejection in Key of the age proxy for experience only reinforces the cultural problem the court said Title VII was intended to correct. Whatever may be true about women in general, the women who were managerial, professional, and supervisory employees at Gillette could well be the exceptions who

56. Id. at 879,881

57. Id. at 881 .

58. Id. at 882 .

59. Id. at $882-83$.

60. Id. at 886; see also Coble v. Hot Springs School Dist. No. 6, 682 F.2d 721, 722 (D.C. Cir. 1982) (citing Trout); Segar v. Civiletti, 508 F. Supp. 690, 712 (D.D.C. 1981). 
have been able to obtain equal experience per year of age as men. Allowing the general cultural situation to justify their disparate treatment only worsens that same situation. A better approach is to require the plaintiff to produce regressions using the best information available, and leave it up to the defendant to produce more accurate information if it believes the plaintiff's model is biased. ${ }^{61}$

\section{V}

\section{CONCLUSION}

Multiple regression models have the potential to become a valuable tool for truth-finding in Title VII litigation. They should not, however, be embraced without question by the courts as conclusive evidence of the presence or absence of discrimination. Nor should they be rejected out of hand because of their complexity or the impossibility of creating a model that perfectly fits its data. Courts and attorneys dealing with multiple regression models should rationally evaluate the capabilities and limitations of each model in the context of the specific fact situation it is designed to illuminate. Only in this way will the truth-finding potential of multiple regression models be fully realized.

61. See D. Baldus \& J. Cole, supra note 3, $\$ 6.222$ (Supp. 1982) (suggests defendant's burden in rebuttal should depend on whether the lack of data was caused by the defendant's negligence or bad faith). 
